\title{
GREENHOUSE COOLING USING EARTH-TUBE HEAT EXCHANGER AND EVAPORATIVE COOLING FOR DURING SUM MER SEASON
}

\author{
Abd El- Latif 1 , S. M.; Radwan'2, S .A.; Hassanain³, A. A.; \\ El-Sheikh ${ }^{4}$, I. H. and Kishk, S. $S^{5}$. \\ ABSTRACT
}

In this research work an attempt has been made to analysis the thermal performance of the earth-tube heat exchanger (ETHE) during summer season of 2012 (June to September). The experimental work was executed in the experimental farm of Faculty of Agriculture, Suez Canal University, Ismailia Governorate, Egypt (Latitude angle of $30.62^{\circ} \mathrm{N}$, Longitude angle of $32.27^{\circ} \mathrm{E}$, and mean altitude above sea level of $5 \mathrm{~m}$ ). The ETHE technique was used to utilize the stability of deep soil temperature for reducing the indoor air temperature during the summer season. A computer simulation model has been developed and used based on MATLAB program to determine the depth at which the soil temperature is stabilized. A comparative study between the evaporative cooling system (based on fan-pads system) and the ETHE system was carried out during the summer season to compare weather the two cooling systems differed significantly in the cooling effectiveness to provide and maintain the indoor air temperature within the two greenhouses at the desired level. The obtained data showed that, the depth at which the soil temperature is stabilized was achieved at $3 \mathrm{~m}$ deep. The overall thermal efficiency of the ETHE system was $73.85 \%$. Due to the microclimatic conditions (air temperature and air relative humidity) were at and around the desired level, the growth rate, flowering rate, fruit set rate, and fresh yield of cucumber crop were at high rates and good quality. Data of the computer simulation model of the indoor air and soil temperatures were found to be very closest to that measured.

Key words: Greenhouses - Earth-tube heat exchanger Evaporative cooling - Air and soil temperatures

\footnotetext{
${ }_{1}^{1}$ Professor Of Agric. Eng., Agric. Eng. Dept. Fac. Agric., El- Mansoura U.

${ }^{2,3}$ Professor, ${ }^{4}$ Assoc. prof. and ${ }^{5}$ Assist. Lect. Of Agric. Eng., Agric. Eng. Dept. Fac. Agric., Suez-Canal U.
} 
NOMENCLATURE

\begin{tabular}{|c|c|c|c|c|c|}
\hline Symbol & Quantity & Units & Symbol & Quantity & Units \\
\hline$\overline{\mathrm{A}_{\mathrm{c}}}$ & the surface area of the cover & $\mathrm{m}^{2}$ & $\mathrm{Q}_{\mathrm{v}}$ & the ventilation rate of floor surface area & $\mathrm{m}^{3} / \mathrm{s} \cdot \mathrm{m}^{2}$ \\
\hline$A_{f}$ & the floor surface area & $\mathrm{m}^{2}$ & $\mathrm{Q}_{\mathrm{ven}}$ & thermal heat loss from greenhouse air due to ventilation & $\mathrm{Wm}^{-2}$ \\
\hline AIWP & annual irrigation water productivity & $L . E / m^{3}$ & $\mathrm{R}_{\mathrm{i}}$ & solar radiation flux incident inside the greenhouse & $\mathrm{Wm}^{-2}$ \\
\hline AIWS & annual irrigation water supply & $m^{3}$ & & temperature & $\mathrm{K}$ \\
\hline$A_{p}$ & the plant surface area & $\mathrm{m}^{2}$ & $\mathrm{~T}_{\mathrm{ai}}$ & inlet air temperature of earth-tube heat exchanger & $\mathrm{K}$ \\
\hline As & soil surface area & $\mathrm{m}^{2}$ & $\mathrm{~T}_{\mathrm{ao}}$ & outlet air temperature of earth-tube heat exchanger & $\mathrm{K}$ \\
\hline$C_{p a}$ & specific heat of dry air & $J k^{-1} k^{-1}$ & $\mathrm{~T}_{\mathrm{c}}$ & cover surface temperature & $\mathrm{Wm}^{-2} \mathrm{k}^{-1}$ \\
\hline $\mathrm{C}_{\mathrm{pex}}$ & the specific heat of air leaving greenhouse & $\mathrm{Jkg}^{-1} \mathrm{k}^{-1}$ & $\mathrm{~T}_{\mathrm{ex}}$ & the temperature of exhaust air leaving greenhouse & ${ }^{\circ} \mathrm{C}$ \\
\hline$C_{p s}$ & Greenhouse soil specific heat & $J k^{-1} K^{-1}$ & $\mathrm{~T}_{\mathrm{f}}$ & equilibrium temperature & $\mathrm{K}$ \\
\hline $\mathrm{D}$ & thickness of the soil layer & $\mathrm{m}$ & $\mathrm{T}_{\mathrm{i}}$ & air temperature inside the greenhouse & $\mathrm{K}$ \\
\hline $\mathrm{E}$ & the evapotranspiration coefficient & - & $\mathrm{T}_{\text {inlet }}$ & the temperature of air entering greenhouse & ${ }^{\circ} \mathrm{C}$ \\
\hline ETHE & Earth to Air Heat Exchanger & - & $\mathrm{T}_{\mathrm{o}}$ & the outside air temperature & ${ }^{\circ} \mathrm{C}$ \\
\hline ETHE & Earth Tube Heat Exchanger & - & $\mathrm{T}_{\mathrm{p}}$ & the plant surface temperature & $\mathrm{K}$ \\
\hline $\mathrm{F}_{\mathrm{p}-\mathrm{c}}$ & shape factor between the plant and cover surface & - & $\mathrm{T}_{\mathrm{s}}$ & sandy soil temperature & $\mathrm{K}$ \\
\hline $\mathrm{F}_{\mathrm{s}-\mathrm{c}}$ & shape factor between the soil and cover surface & - & $\mathrm{T}_{\mathrm{sk}}$ & the sky temperature & $\mathrm{K}$ \\
\hline$F_{s-p}$ & shape factor between soil and plant surface & - & $\mathrm{T}_{\text {sub }}$ & soil bulk temperature & $\mathrm{K}$ \\
\hline $\mathrm{h}_{\mathrm{fg}}$ & latent heat of vaporization of water & $\mathrm{kJkg}^{-1}$ & $\mathrm{~T}_{\mathrm{w}}$ & water temperature & $\mathrm{K}$ \\
\hline $\mathrm{h}_{\mathrm{i}}$ & $\begin{array}{l}\text { convective heat transfer coefficient of the inside } \\
\text { greenhouse }\end{array}$ & $\mathrm{Wm}^{-2} \mathrm{k}^{-1}$ & $\mathrm{U}$ & the overall heat transfer coefficient & $\mathrm{W} / \mathrm{m}^{2 \circ} \mathrm{C}$ \\
\hline $\mathrm{h}_{\mathrm{o}}$ & $\begin{array}{l}\text { convective heat transfer coefficient of the outside } \\
\text { greenhouse cover }\end{array}$ & & $\mathrm{V}$ & wind speed & $\mathrm{ms}^{-1}$ \\
\hline $\mathrm{h}_{\mathrm{p}}$ & convective heat transfer coefficient of the plant & $\mathrm{Wm}^{-2} \mathrm{k}^{-1}$ & $\mathrm{~V}_{\mathrm{ex}}$ & the specific volume of air leaving greenhouse & $\mathrm{m}^{3} / \mathrm{kg}_{\text {air }}$ \\
\hline $\mathrm{h}_{\mathrm{s}}$ & $\begin{array}{l}\text { convective heat transfer coefficient between the } \\
\text { greenhouse soil and indoor air }\end{array}$ & $\mathrm{Wm}^{-2} \mathrm{k}^{-1}$ & $\mathrm{VP}_{\mathrm{air}}$ & air vapour pressure & $\mathrm{kPa}$ \\
\hline I & the solar radiation of floor area & $\mathrm{W} / \mathrm{m}^{2}$ & VPD & vapour pressure deficit & $\mathrm{kPa}$ \\
\hline IWUE & Irrigation water use efficiency & $\mathrm{kg} / \mathrm{m}^{3}$ & $\mathrm{VP}_{\text {sat }}$ & saturation vapour pressure & $\mathrm{kPa}$ \\
\hline $\mathrm{k}$ & Soil Thermal Conductivity & $W m^{-1} K^{-1}$ & $\mathrm{~W}_{\mathrm{ac}}$ & humidity ratio of air at the given cover temperature & $\mathrm{kg} \mathrm{kg}^{-1}$ \\
\hline$\dot{m}$ & mass flow rate of air & $\mathrm{kg} \mathrm{s}^{-1}$ & $\mathrm{~W}_{\mathrm{ai}}$ & humidity ratio of the greenhouse air & $\mathrm{kg} \mathrm{kg}^{-1}$ \\
\hline $\mathrm{P}_{\mathrm{wvs}}$ & saturated vapour pressure & $\mathrm{kPa}$ & $\mathrm{W}_{\mathrm{ap}}$ & humidity ratio of air at the given plant surface temperature & $\mathrm{kg} \mathrm{kg}^{-1}$ \\
\hline$Q_{(\mathrm{C}-\mathrm{s})}$ & convective heat transfer from the soil surface & $\mathrm{Wm}^{-2}$ & $\mathrm{~W}_{\mathrm{as}}$ & humidity ratio of air at the given soil surface temperature & $\mathrm{kg} \mathrm{kg}^{-1}$ \\
\hline $\mathrm{Q}_{(\mathrm{Sh}-\mathrm{s})}$ & solar radiation absorbed by soil surface & $\mathrm{Wm}^{-2}$ & $\alpha$ & thermal diffusivity of soil & $\mathrm{m}^{2} \mathrm{~s}^{-1}$ \\
\hline $\mathrm{Q}_{\mathrm{C}(\mathrm{c}-\mathrm{i})}$ & convective heat energy at inside cover surface & $\mathrm{Wm}^{-2}$ & $\alpha_{\mathrm{p}}$ & leaf surface absorption & - \\
\hline $\mathrm{Q}_{\mathrm{C}(\mathrm{c}-\mathrm{o})}$ & convective heat at outside cover surface & $\mathrm{Wm}^{-2}$ & $\alpha_{\mathrm{s}}$ & soil surface absorption & - \\
\hline$Q_{\text {cond }}$ & conductive heat transfer from the soil & $\mathrm{Wm}^{-2}$ & $\gamma$ & ventilation rate & $\mathrm{m}^{3} \mathrm{~s}^{-1}$ \\
\hline$Q_{\text {conden }}$ & heat flow due to condensation on the cover & $\mathrm{Wm}^{-2}$ & $\varepsilon_{\mathrm{c}}$ & greenhouse cover emissivity & - \\
\hline$Q_{\text {earth }}$ & $\begin{array}{l}\text { heating potential obtained from the earth-tube heat } \\
\text { exchanger }\end{array}$ & $\mathrm{Wm}^{-2}$ & $\varepsilon_{\mathrm{p}}$ & emissivity factor of the plant & - \\
\hline Qevap & $\begin{array}{l}\text { latent heat from the soil to the inside air due to } \\
\text { evaporation }\end{array}$ & $\mathrm{Wm}^{-2}$ & $\varepsilon_{\mathrm{s}}$ & soil surface emissivity & - \\
\hline $\mathrm{Q}_{\mathrm{exc}}$ & heat exchanging rate, & Watt & $\zeta_{\mathrm{p}}$ & water covering ratio of the leaf surface & - \\
\hline $\mathrm{Q}_{\mathrm{G}}$ & solar heat gain & $\mathrm{Wm}^{-2}$ & $\zeta_{\mathrm{s}}$ & water covering ratio of the soil surface & - \\
\hline Qloss & heat loss from the greenhouse element & $\mathrm{Wm}^{-2}$ & $\eta$ & effectiveness of earth tube heat exchanger & $\%$ \\
\hline $\mathrm{Q}_{\mathrm{r}(\mathrm{c}-\mathrm{sk})}$ & $\begin{array}{l}\text { longwave radiant heat emitted from the cover to the } \\
\text { ambient air }\end{array}$ & $\mathrm{Wm}^{-2}$ & $\rho_{\mathrm{a}}$ & density of the air & $\mathrm{kgm}^{-3}$ \\
\hline $\mathrm{Qr}_{\mathrm{r}(\mathrm{p}-\mathrm{c})}$ & radiant heat exchange between the plant and the cover & $\mathrm{Wm}^{-2}$ & $\rho_{\mathrm{s}}$ & The density of the sand soil & $\mathrm{kg} \mathrm{m}^{-3}$ \\
\hline $\mathrm{Q}_{\mathrm{r}(\mathrm{s}-\mathrm{c})}$ & radiant heat exchange between the soil and the cover & $\mathrm{Wm}^{-2}$ & $\sigma$ & Stefan-Boltzmann constant & $\mathrm{Wm}^{-2} \mathrm{~K}^{-4}$ \\
\hline $\mathrm{Q}_{\mathrm{r}(\mathrm{s}-\mathrm{p})}$ & radiant heat exchange between the soil and the plant & $\mathrm{Wm}^{-2}$ & $\tau_{\mathrm{c}}$ & The effective transmissivity of the cover & \\
\hline $\mathrm{Q}_{\text {sub }}$ & heat supplied to the greenhouse element & $\mathrm{Wm}^{-2}$ & & & \\
\hline
\end{tabular}

\section{INTRODUCTION}

gricultural greenhouses have been proven a viable solution to
world-wide increased demand for expanding production,
facilitating out of season cultivation and protecting crops from unfavorable outdoor conditions. Cooling is considered as the basic necessity for greenhouse crop production in tropical and subtropical 
regions to overcome the problems of high temperatures during summer months (Kumar et al., 2009). Kittas et al. (2005) described the forced ventilation (using fan) in a multi-span greenhouse. The results showed that the difference between inside and outside air temperature was strongly related to the ventilation rate as well as to the incoming solar radiation. During the summer, application of shading compounds to the greenhouse cover can reduce the infrared portion of solar spectrum. Shading can be done by various methods such as the use of paints, external shade cloths and use of nets. Ali et al. (1990) developed an efficient greenhouse design for hot climatic conditions of Kuwait. The roof was shaded with a screen mesh (55\% shade). Fan-pad system was also used during peak hours to control the inside air temperature. The results showed that combination of shading and fan-pad during peak summer maintained temperature of $30^{\circ} \mathrm{C}$ during the day and $22^{\circ} \mathrm{C}$ during night in the greenhouse. Shukla et al. (2008) studied the effect of inner thermal curtain in the evaporative cooling. The results indicated that use of inner thermal curtain reduced the greenhouse temperature by $5^{\circ} \mathrm{C}$. Evaporative cooling is the most effective cooling method for controlling the temperature and humidity inside a greenhouse (Sethi and Sharma, 2007). This system consists of a fan on one sidewall and pad on the other side of the greenhouse. Kittas et al. (2001) investigated the temperature and humidity gradients during summer in a rose production greenhouse equipped with a ventilated cooling-pad system and a half shaded plastic roof. The cooling performance was achieved up to $80 \%$ and the temperature of the greenhouse was lowered by $10^{\circ} \mathrm{C}$ than the outside air. Jain and Tiwari (2002) conducted theoretical and experimental studies in a $24 \mathrm{~m}^{2}$ greenhouse with a fan-pad evaporative cooling system of $3 \mathrm{x}$ $1.15 \mathrm{~m}^{2}$ area. Greenhouse air temperature was reported $4-5^{\circ} \mathrm{C}$ lower as compared to the outside conditions. It is well known that the temperature of the ground at a depth of about 2.5 to $3 \mathrm{~m}$ remains fairly constant (Bisoniya et al., 2013). The most common technique to couple structures (such as greenhouses) with the ground is the use of underground air tunnels, known as earth-tube heat exchangers (ETHE). The main advantages of ETHE system are its simplicity, high cooling and preheating potential, low operational and maintenance costs. Earth tube heat 
exchanger consist of pipes which are buried in the soil while an air circulation system forces the air through the pipes and eventually mixes it with the indoor air of the building or the agricultural greenhouse (Ascione et al., 2011). In summer, the warm air from the greenhouse, sucked through the suction pipe, gives up its heat content to the buried pipe by convection, which is then dissipated to the earth by conduction. The cool air from the heat exchanger is then entered into the greenhouse (Ghosal and Tiwari, 2006). Kassem (1999) studied the potential of using the deep soil as a renewable source of heating and cooling ambient air for protected agriculture. He found that the thermal performance of earth-tube heat exchanger was directly proportional to temperature difference between the outlet and inlet airflow and inversely proportional to the temperature difference between tube surface and the inlet airflow. Kumar et al. (2003) developed a numerical model to predict energy conservation potential of earth-air heat exchanger system. Results showed that the cooling potential of $80 \mathrm{~m}$ earth tunnel was found adequate $(19 \mathrm{~kW})$ to maintain an average room temperature of $27.7^{\circ} \mathrm{C}$. Ghosal et al. (2004) developed a simplified analytical model to investigate the potential of using the stored thermal energy of the ground for greenhouse cooling with help of an earth to air heat exchange (EAHE). The temperatures of the greenhouse air of EAHE were $5-6^{\circ} \mathrm{C}$ lower than greenhouse without EAHE. Ghosal and Tiwari (2006) developed a new thermal model for greenhouse heating and cooling with EAHE in New Delhi, India. It was found on average $7-8^{\circ} \mathrm{C}$ higher in the winter and $5-6^{\circ} \mathrm{C}$ lower in the summer than those of the same greenhouse without EAHE. Tiwari et al. (2006) studied the annual thermal performance of greenhouse with an earth- air heat exchanger. They found that the temperature of the greenhouse increased and decreased by 8 and $4^{\circ} \mathrm{C}$ in summer and winter respectively, due to use of an EAHE. Al-Ajmi et al. (2006) studied the cooling capacity of the earth-air heat exchangers for domestic buildings in a desert climate in Kuwait. Simulation results showed that the EAHE could provide a reduction of $1700 \mathrm{~W}$ in the peak cooling load, with an indoor temperature reduction of $2.8^{\circ} \mathrm{C}$ during summer peak hours. Bansal et al. (2010) investigated the performance analysis of EAHE for summer cooling in Jaipur, India. They showed that 
the EAHE system discussed gives cooling in the range of $8.0-12.7^{\circ} \mathrm{C}$ for the flow velocities $2-5 \mathrm{~m} / \mathrm{s}$. Chel and Tiwari (2010) studied photovoltaic (PV) integrated with earth to air heat exchanger (EAHE) for space heating/cooling of adobe house in New Delhi (India). Results showed successfully used earth to air heat exchanger (EAHE) for heating and cooling of adobe house. Woodson et al. (2012) presented a case study to examine the ground temperature gradient and performance of EAHE in Burkina Faso. Experiments were conducted at burial depth of $0.5,1.0$ and $1.5 \mathrm{~m}$. It is concluded that about $7.6^{\circ} \mathrm{C}$ decreases in outdoor temperature is achieved with $25 \mathrm{~m}$ long EAHE buried at depth of $1.5 \mathrm{~m}$. The objective of this study is use earth-tube heat exchanger and evaporative cooling as a method to overcome the high temperature during daylight time within summer season, which affects the greenhouse crop production.

\section{Experimental Set-up}

The experimental work was carried out in the experimental farm of Faculty of Agriculture, Suez Canal University, Ismailia Governorate, Egypt (Latitude angle of $30.62^{\circ} \mathrm{N}$, Longitude angle of $32.27^{\circ} \mathrm{E}$, and mean altitude above sea level of $5 \mathrm{~m}$ ). It was executed during summer season of 2012 ( $^{\text {st }}$ of June to $2^{\text {nd }}$ of September) study compared between the effectiveness of evaporative cooling system (fan-pad system) and the earth-to-air heat exchanger for cooling two identical greenhouses during summer season. Two similar gable-even-span form greenhouses were designed, constructed, and operated during this research work. The geometric characteristics of the gable-even-span greenhouse are as follows: eaves height $2.933 \mathrm{~m}$, gable height $0.933 \mathrm{~m}$, rafter angle $25^{\circ}$, total width $4.0 \mathrm{~m}$, total length $6.0 \mathrm{~m}$, floor surface area $24 \mathrm{~m}^{2}$, and volume $60.00 \mathrm{~m}^{3}$ as shown in Figure (1). The greenhouse structural frame is formed of $25.4 \mathrm{~mm}$ hot dipped galvanized pipes (1 inch) with excellent anti-corrosion. The rafter length of the greenhouse gable is $2.207 \mathrm{~m}$ and gable height is $0.933 \mathrm{~m}$, whilst the height of each vertical side wall is $2 \mathrm{~m}$. The two identical greenhouses (G1 and G2) were covered using double layer of UV polyethylene sheets of $150 \mu \mathrm{m}$ thick and black net sheet. To maintain the durability of structural frame of plastic greenhouses and prevent pad side effects of wind load on the 
polyethylene cover, twenty tensile compacted plastic wires $(2 \mathrm{~mm}$ diameter) were tied and fixed throughout the rafters and vertical pipes of walls in the two longitudinal sides. The earth-tube heat exchanger was made from PVC pipes buried under the ground at $3 \mathrm{~m}$ in sandy soil. The dimensions of the earth-tube heat exchanger were $20 \mathrm{~m}$ long and $0.144 \mathrm{~m}$ inner diameter (Figure 2). A portable blower of $335 \mathrm{~W}$ and flow rate of $1200 \mathrm{~m}^{3} \mathrm{~h}^{-1}$ has been fitted at the suction end of the pipe positioned in the center south side of the greenhouse. Fan and pad cooling system consist of exhaust fans at one end of the greenhouse and a pump circulating water through a porous pad installed at the opposite end of the greenhouse. A cooling pad size of dimensions (1.8 m width, $2 \mathrm{~m}$ height, and $10 \mathrm{~cm}$ thickness) on the east wall (Figure (3)). Two suction fans (single speed, $50 \mathrm{~cm}$ diameter, and $2500 \mathrm{~m}^{3} \mathrm{~h}^{-1}$ discharge) were located on the west side. A suitable pump (0.5 HP, $2850 \mathrm{rpm}, 220$ Volt and 20 $1 /$ min discharge) with a water tank was attached to the cooling pad for continuous water trickling (Figure 3).

The mechanical analysis of the greenhouse soil was conducted according to the international pipette method (Arnold et al., 1986) to determine the soil structures as presented in Table (1). Drip irrigation system was used inside the two greenhouses during the experimental period, for watering root media of cucumber crop. The fertilizer was directly added to the soil and vegetative fertilization was also used to obtain a higher growth and production.

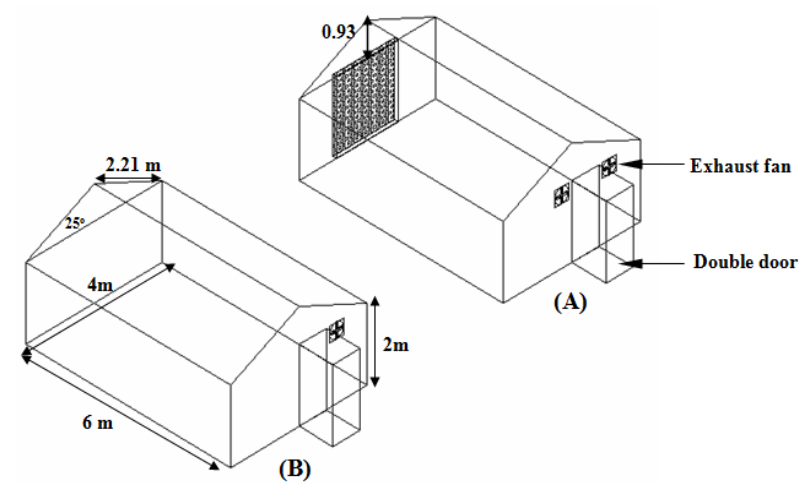

Figure (1): Schematic diagram of gable even-span greenhouses (A) Greenhouse with evaporative cooling (B) Greenhouse with earth-tube heat exchanger cooling

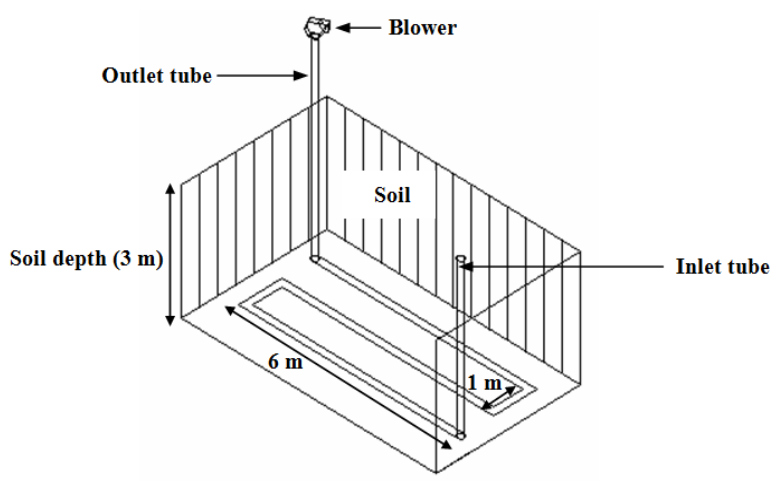

Figure (2): Diagram of the earth-tube heat exchanger 
Table (1): Structure of the experimental soil

\begin{tabular}{|c|c|c|c|c|}
\hline \multicolumn{4}{|c|}{ Soil structure \% } & \multirow{2}{*}{$\begin{array}{c}\text { Texture } \\
\text { grade }\end{array}$} \\
\hline Coarse sand & Fine sand & Silt & Clay & \\
\hline 68.93 & 26.04 & \multirow{2}{*}{3.81} & \multirow{2}{*}{1.22} & \multirow{2}{*}{ Sandy } \\
\hline Total & .97 & & & \\
\hline
\end{tabular}

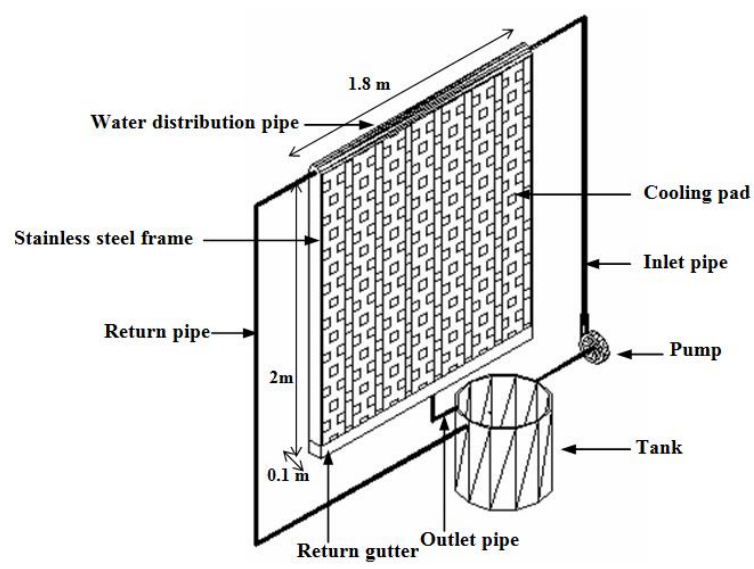

\section{Figure (3): Diagram of the evaporative cooling fan-pad system}

For the rest of this research, the greenhouse equipped with the earth-tube heat exchanger system and the greenhouse provided by the evaporative cooling system are referred to as G1 and G2, respectively.

\section{Methodology and instrumentations}

Meteorological station (Vantage Pro 2, Davis, USA) was used to measure different macroclimate variables such as, the solar radiation flux incident on a horizontal surface (pyranometer), dry-bulb, wet-bulb, and dew-point air temperatures, wind speed and its direction, air relative humidity and rainfall amounts. For the duration of the whole year of 2011, the temperature distribution in the earth at different depths of $0.0,1.0,2.0$ and $3.0 \mathrm{~m}$ was measured and recorded to assess the specific depth of earth at which the relative temperature remains sufficiently high and low for effective heating and cooling modes performance, respectively. Eight thermocouples were vertically located in the earth at different depths starting at $0.0 \mathrm{~m}$ deep and continuing at $1.0 \mathrm{~m}$ intervals to a depth of 3.0 $\mathrm{m}$ (two thermocouples were used to measure each point). The two greenhouses soil temperatures were measured at four different depths of $0.0,10.0,20.0$, and $30.0 \mathrm{~cm}$ using four thermocouples in each 
greenhouse. These depths represent the most root zone of cucumber crop (20-30 cm) as mentioned by Hassan (2001). The inlet and outlet air temperature of the earth-tube heat exchanger were measure using four thermocouples. Data included the measured indoor dry-bulb and wetbulb temperatures were functioned to determine the indoor air relative humidity of the two greenhouses using a specific software computer program (Sonntage and Borgnakke, 1988). These sensors were connected to a data-logger system (Lab-Jack logger, powered by USB cable, supply 4-5.25 volt, USA) to display, and record the data during the experimental period. Mono Crestline solar cell $(75 \mathrm{~mm}$ x $75 \mathrm{~mm}, 0.5$ volt, current of $800 \mathrm{~mA}$, kemo, 139, Germany) was used to measure the global solar radiation. Formula was functioned to determine the solar radiation flux incident according to Mujahid and Lamoud (1988). The Mono Crestline solar cell was calibrated with a Kipp pyranometer (Kipp and Zohne, Australia) under clear sky conditions. The short circuit reading obtained from the solar cell was measured using a digital multimeter (M3800, China) according to Duffie and Beckman (1991). The solar cell and the Kipp pyranometer were placed in the same horizontal plane. One hundred readings were taken and recorded inside and outside the greenhouse. The effective transmissivity $\left(\tau_{c}\right)$ of the double layer of UV polyethylene sheet was determined using the following equation:

$$
\tau_{\mathrm{c}}=\frac{\text { Solar radiation inside the greenhouse }}{\text { Solar radiation outside the greenhouse }} \times 100
$$

The effective transmissivity of the double layer polyethylene sheet with black net sheet was $63 \%$.

The thermal conductivity of the sandy soil was determined using the method of Lewis (1990). From the above method the average thermal conductivity of the sandy soil was found to be $0.97 \mathrm{~W} \mathrm{~m}^{-1} \mathrm{~K}^{-1}$.

The specific heat $\left(\mathrm{C}_{\mathrm{ps}}\right)$ of the sandy soil was determined in $\mathrm{J} \mathrm{kg}^{-1} \mathrm{~K}^{-1}$ using locally made calorimeter device according to the following equation (Klute, 1986). This method was applied on three different samples of sandy soil. The average specific heat was found to be $924 \mathrm{~J} \mathrm{~kg}$ ${ }^{-1} K^{-1}$. The density of the sand soil $\left(\rho_{s}\right)$ was deduced and determined using the method of paraffin wax (Black, 1965). It was found to be 1442 
$\mathrm{kg} \mathrm{m}^{-3}$. The thermal conductivity $(\mathrm{k})$, density $\left(\rho_{\mathrm{s}}\right)$, and the specific heat of sandy soil were functioned to deduce the thermal diffusivity $(\alpha)$ using the following equation (Incropera and Dewitt, 1996):

$$
\alpha=\frac{k}{\rho_{s} C_{p s}}
$$

The thermal diffusivity of the sandy soil which utilized in this research work was found to be $7.28 \times 10^{-7} \mathrm{~m}^{2} \mathrm{~s}^{-1}$.

\subsection{Effectiveness of earth-tube heat exchanger (ETHE)}

The effectiveness of the earth-tube heat exchanger $(\eta)$ was computed using the following two equations (Al-Ajmi et al., 2006):

$$
\eta=\frac{\mathrm{T}_{\mathrm{ai}}-\mathrm{T}_{\mathrm{ao}}}{\mathrm{T}_{\mathrm{ai}}-\mathrm{T}_{\mathrm{s}}} \times 100
$$

The potential heating acquired from the earth-tube heat exchanger $\left(\mathrm{Q}_{\mathrm{exc}}\right)$ can be calculated using the following equation (Al-Ajmi et al., 2006; Li et al., 2014):

$$
\mathrm{Q}_{\mathrm{exc}}=\dot{m} \mathrm{C}_{\mathrm{pa}}\left(\mathrm{T}_{\mathrm{ao}}-\mathrm{T}_{\mathrm{ai}}\right)
$$

\subsection{Experimental procedure and data analysis for cucumber crop}

The effect of microclimatic conditions of the greenhouses on cucumber crop growth stages (vegetative growth, flowering, fruit set rate, and fresh yield) were estimated. The stem length of cucumber plants was measured every week from the transplanting date inside the two greenhouses. Flowering measurement was taken every day after four weeks of transplanting date. Fresh yield of cucumber crop were measured in kilogram twice every week during the harvesting period. Finally, the total fresh yield per square meter for each greenhouse was determined. The changes in the growth of cucumber plants and the water consumption through irrigation operation are mainly determined and expressed by the dry weight characteristic after the last harvesting operation. Dry weight characteristic is a good indicator for growth of greenhouse protected cropping. Dry weight was also functioned to determine the total water consumption throughout the growing period of the greenhouse crops. Aldrich and Bartok (1990) reported that, each 28 grams of dry weight of greenhouse crop consume 7.5 litres of water during the complete growth. From the previous information, the amount of irrigation water in cubic meter (annual irrigation water supply, AIWS) during the growing 
period can be computed. The annual irrigation water productivity (AIWP) is defined as the total value of crop production in L.E to the annual irrigation water supply in cubic meter. It can be computed as follows:

$$
A I W P=\frac{\text { Total value of crop production (L.E.) }}{A I W S\left(m^{3}\right)} \text { L.E. } \mathrm{m}^{-3}
$$

The Irrigation water use efficiency (IWUE) is defined as the ratio of the marketable crop yield in $\mathrm{kg}$ to the annual irrigation water supply in cubic meter. It can be determined as follows:

$$
I W U E=\frac{\text { Marketable crop yield }(\mathrm{kg})}{A I W S\left(\mathrm{~m}^{3}\right)} \mathrm{kg} \mathrm{m}^{-3}
$$

\subsection{Vapour pressure deficit (VPD)}

Vapour pressure deficit (VPD) is a valuable way to measure greenhouse climate. VPD can be used to evaluate the disease threat, condensation potential, and irrigation needs of a greenhouse crop. The differences between the saturation vapour pressure and the actual air vapour pressure $\left(\mathrm{VP}_{\text {sat }}-\mathrm{Vp}_{\text {air }}\right)$ is the mathematical definition of vapour pressure deficit (VPD). Higher vapour pressure deficit means that the air has a higher capacity of hold water, stimulating water vapour transfer (transpiration) into the air in this low humidity condition. Lower vapour pressure deficit, on the other hand, means the air is at or near saturation, so the air can not accept moisture from a leaf in this high humidity conditions (Pringer and Ling, 2004).

\section{Mathematical simulation model}

\subsection{Greenhouse energy balance}

Environmental control of the greenhouse may be included the control of solar radiation, heat losses and gain, energy conservation, and humidity control. A greenhouse cover with high transmissivity for solar energy can produce temperatures that are higher than desired in the crop zone. Most surfaces within a greenhouse have high absorptivity for solar energy. Figure (4) shows energy exchange for a greenhouse during daylight when the sun's rays strike the surface at a right angle to the surface. Emissivity is the ratio of the total radiation emitted by a body to the total radiation emitted by a black body for the same time period (Nelson, 2006). 
Traditional cooling alternatives for greenhouses depend upon exhaust fans to remove excess heat energy. As outside air is brought into and then through the greenhouse, its energy level rises due to sensible heat gain from the canopy, ground and surrounding structure. The volume of air required to maintain a given temperature rise $\left(\mathrm{T}_{\mathrm{ex}}-\mathrm{T}_{\text {inlet }}\right)$, may be estimated using the following approximate energy balance (ANSI/ASAE, 2003):

$$
(1-\mathbf{E}) \tau_{c} I A_{f}=U A_{c}\left(T_{i}-T_{0}\right)+\frac{Q_{v} A_{f} C_{p e x}}{V_{e x}}\left(T_{e x}-T_{\text {inlet }}\right)
$$

A mathematical model of the greenhouse consisting of a set of algebraic equations was proposed. The equations were written for the five components of the greenhouse (cover, plant, earth-tube heat exchanger, indoor air and bare soil surface). The values of dimensions and material properties of the greenhouse have been substituted in these equations. The equations were solved using a computer program written in MATLAB (MATrix LABortary, USA) to predict the indoor air temperature, plant temperature, cover temperature and soil surface temperature. The output data of the computer model (predicted) were then compared with the experimental data (measured). Flow chart for solution of equations for the greenhouse model is given in Figure (5).

Energy balance equations for various components of the greenhouse combined with the earth-tube heat exchanger can be written based on the following assumptions:

- Analysis based on quasi-steady state condition.

- Temperatures of shading cloth and greenhouse cover are all the same.

- Heat conduction through the bottom layer of the ground is onedimensional.

- Flow of air is uniform along the length of the buried pipes.

- The pipes are uniform circular cross-section.

- The soil surrounding the pipe is homogenous and has constant thermal conductivity.

\subsection{Energy balance on greenhouse cover}

Greenhouse cover is exposed to solar radiation and exchange thermal radiation with the plants, soil, and sky. Convective heat transfer takes place from the cover to the outside depending on wind speed. 
Condensation could also be detected on the cover depending upon the saturated humidity ratios at both the cover surface and inside air. An energy balance equation can be written for the greenhouse cover as follows (Ibrahim, 1999):

$$
Q_{C(c-o)}+Q_{C(c-i)}+Q_{r(s-c)}+Q_{r(c-s k)}+Q_{r(p-c)}+Q_{\text {Conden }}=0
$$

The convection heat transfer from the outside cover surface was determined as follows (Norton, 1992):

$$
Q_{C(c-o)}=h_{o}\left(T_{c}-T_{o}\right)
$$

The rate of heat transfer by the greenhouse covering sheet convection is highly dependent on wind speed. The relationship between the wind speed and the convection heat transfer coefficient $\left(h_{\text {out }}\right)$ is given by Mc Adams (1954) as:

$$
h_{o}=1.98\left(V^{0.8}\right)
$$

The convective heat loss from the inside cover surface to ambient air was computed by the following equation (Hollman, 2010):

$$
Q_{C(c-i)}=h_{i}\left(T_{c}-T_{i}\right) \quad, \quad h_{i n s}=4.36\left(T_{i}-T_{c}\right)^{0.25}
$$

The thermal radiant heat exchange between the cover and the soil was determined using the following equation (El-Sheikh, 2001):

$$
Q_{r(s-c)}=F_{s-c} \sigma \frac{A_{s}}{A_{c}}\left(T_{s}^{4}-T_{c}^{4}\right) \quad, \quad F_{s-c}=\frac{1}{\frac{1}{\varepsilon_{s}}+\frac{A_{s}}{A_{c}}\left(\frac{1}{\varepsilon_{c}}-1\right)}
$$

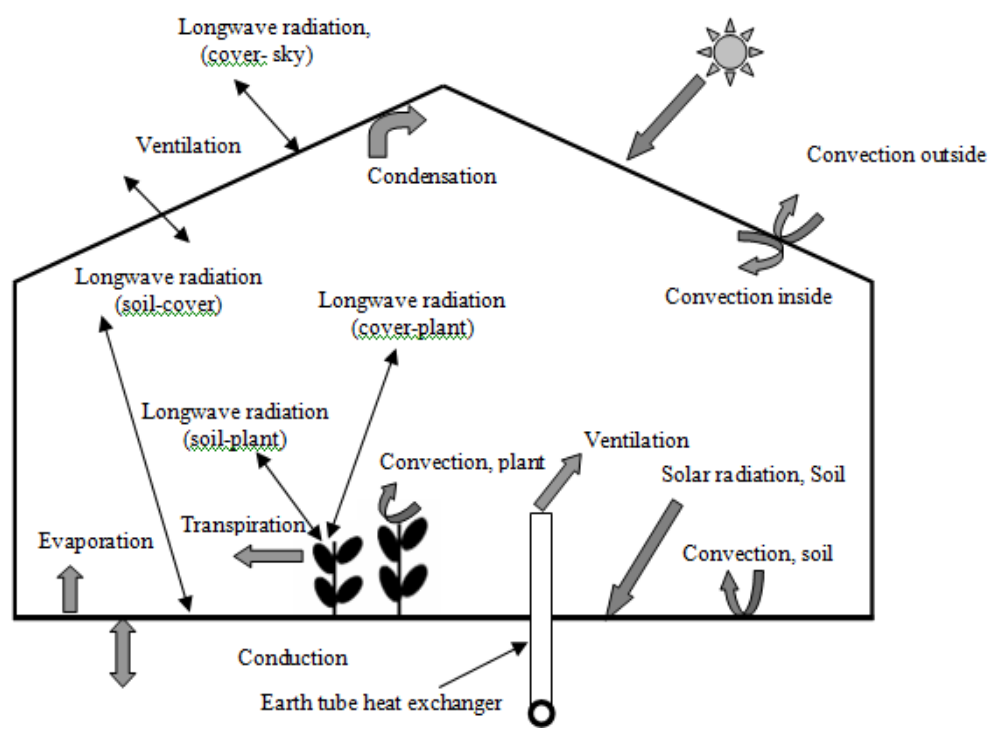

Figure (4): Schematic diagram of the heat energy balance occurring on the greenhouse 
BIOLOGICAL ENGINEERING

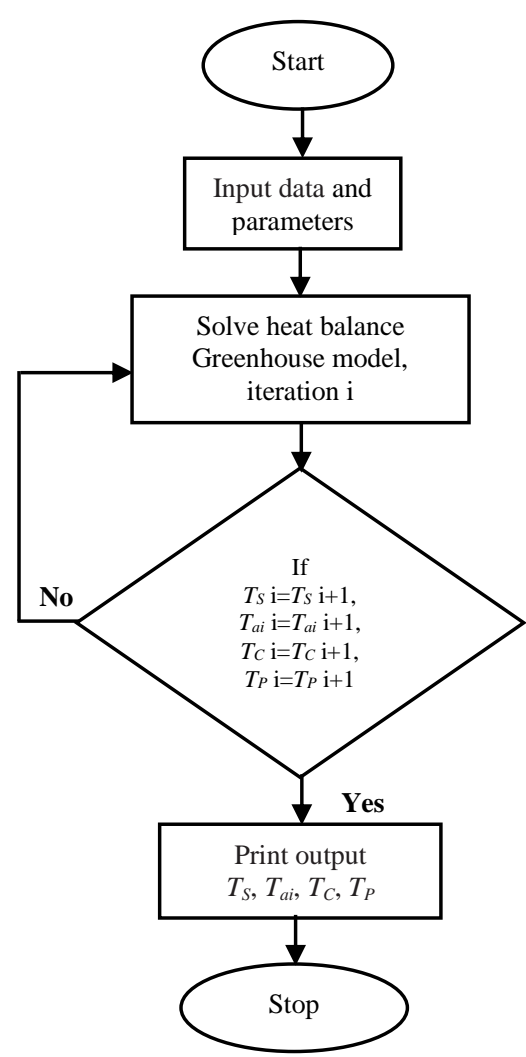

Figure (5): Flow chart of the greenhouse model

The longwave radiant heat emitted from the cover to the ambient air can be estimated as follows (Taha, 2003):

$$
Q_{r(c-s k)}=\varepsilon_{c} \sigma\left(T_{c}^{4}-T_{s k}^{4}\right)
$$

The sky temperature can be calculated from the following equation (Pieters et al., 1994): $T_{s k}=0.0552\left(T_{a o}\right)^{1.5}$

The thermal radiant heat exchange between the plant and the cover was determined using the following equation (El-Sheikh, 2001):

$$
Q_{r(p-c)}=F_{p-c} \sigma \frac{A_{p}}{A_{c}}\left(T_{p}^{4}-T_{c}^{4}\right), \quad F_{p-c}=\frac{1}{\frac{1}{\varepsilon_{p}}+\frac{A_{p}}{A_{c}}\left(\frac{1}{\varepsilon_{c}}-1\right)}
$$

Condensation may occur if the humidity ratio of the greenhouse air is greater than that of the saturated air at the temperature of the cover. The heat flow due to condensation on the cover can is expressed as follows (Garzoli, 1985): 


$$
Q_{\text {conden }}=\frac{h_{i n s}}{C_{p a}} h_{\mathrm{fg}}\left(W_{a i}-W_{a c}\right)
$$

Humidity ratio was determined using the following equations (Lewis, 1990):

$$
W_{a i}=\frac{18 P_{w v}}{29\left(P_{a}-P_{w v}\right)}, \quad W_{a c}=\frac{18 P_{w v s}}{29\left(P_{a}-P_{w v s}\right)}, \quad P_{w v}=0.61078 \exp \left(\frac{17.2693882 T}{T+237.3}\right)
$$

\subsection{Energy balance of greenhouse soil}

An energy balance equation for the bare soil surface can be written as follows:

$$
Q_{(S h-s)}+Q_{(C-s)}+Q_{r(c-s)}+Q_{r(s-p)}+Q_{\text {cond }}+Q_{\text {evap }}=0
$$

The solar radiation absorbed by the soil surface can be determined as follows:

$$
Q_{(S h-s)}=(1-E) \alpha_{s} R_{i}
$$

The convective heat transfer from the soil surface can be computed as follows:

$$
Q_{(C-s)}=h_{s}\left(T_{s}-T_{i}\right), \quad h_{s}=2.5\left(T_{s}-T_{i}\right)^{0.25}
$$

The thermal radiant heat exchange between the soil and the plant was determined using the following equation:

$$
Q_{r(s-p)}=F_{s-p} \frac{A_{s}}{A_{p}}\left(T_{s}^{4}-T_{p}^{4}\right), \quad F_{s-p}=\frac{1}{\frac{1}{\varepsilon_{s}}+\frac{A_{s}}{A_{p}}\left(\frac{1}{\varepsilon_{p}}-1\right)}
$$

The conductive heat transfer from the soil can be expressed as follows:

$$
Q_{\text {cond }}=k\left(T_{s}-T_{\text {sub }}\right) / d
$$

The latent heat from the soil to the inside air due to evaporation is given by the following equation:

$$
Q_{\text {evap }}=\frac{h_{s}}{C_{p a}} h_{\mathrm{fg}} \zeta_{s}\left(W_{a i}-W_{a s}\right)
$$

\subsection{Energy balance of plant}

An energy balance equation can be written for the plant as follows:

$$
Q_{a b s}+Q_{(C-p)}+Q_{r(c-p)}+Q_{r(s-p)}+Q_{\text {Trans }}=0
$$

The solar radiation at the plant can be determined as follows:

$$
Q_{a b s}=\alpha_{p} R_{\mathrm{i}}
$$

The convective heat transfer from the plant surface can be computed as follows:-

$$
Q_{C-p}=h_{p}\left(T_{p}-T_{i}\right) \quad, h_{p}=2.5\left(T_{p}-T_{i}\right)^{0.25}
$$


The latent heat from the plant to the inside air due to transpiration is given by the following equation:-

$$
Q_{\text {Trans }}=\frac{h_{p}}{C_{p a}} h_{f g} \zeta_{p}\left(W_{a i}-W_{a p}\right)
$$

\subsection{Energy balance of indoor air}

An energy balance equation can be written for the indoor air of greenhouse as follows:

$$
Q_{G}+Q_{(C-c)}+Q_{(C-s)}+Q_{(C-p)}+Q_{v e n}+Q_{\text {earth }}=0
$$

The solar gain can be estimated by the following equation:-

$$
Q_{G}=A_{f} R_{\mathrm{i}}
$$

The heat flow from inside to outside due to ventilation through ventilations openings can be calculated by using the following formula:

$$
Q_{v e n}=\rho_{a} \gamma c_{p a}\left(T_{i}-T_{o}\right)
$$

The heating potential obtained from the earth-tube heat exchanger was calculated as the following expression: (Ghosal and Tiwari, 2006; AlAjmi et al., 2006; Li. et al., 2014)

$$
\mathrm{Q}_{\text {supply }}=\dot{m} \mathrm{C}_{\mathrm{pa}}\left(\mathrm{T}_{\mathrm{i}}-\mathrm{T}_{\mathrm{ao}}\right)
$$

\subsection{Deep Soil as an Energy Source}

\section{RESULTS AND DISCUSSIONS}

For the duration of the whole year the temperature gradients in the earth at different depths of 1.0, 2.0 and $3 \mathrm{~m}$ and the maximum and the minimum ambient air temperatures were examined, measured and recorded to assess the specific depth of earth at which the relative temperature remains sufficiently high or low for effective cooling performance. The obtained data are summarized and listed in Table (2). The $3 \mathrm{~m}$ deep soil temperature on average remained constant at $23.2^{\circ} \mathrm{C}$ during the three months period of summer season whilst, the daily average maximum ambient air temperature for the three months was 35.8 ${ }^{\circ} \mathrm{C}$ that gave an average potential difference of $12.6^{\circ} \mathrm{C}$. This peripheral deep soil temperature is essentially stable due to the tremendous thermal capacity of the sandy soil. During daylight, when the ambient air temperature is mainly increased and reached to higher than $36.9^{\circ} \mathrm{C}$ (such as on August month), a great rate of energy exchange (5.064 kW) is occurred and consequently created a good potential for cooling mode. 
Table (2): Monthly average daily maximum and minimum ambient air temperatures and peripheral deep soil temperature at different depths for the summer months of 2012

\begin{tabular}{||c|c|c|c|c|c|c||}
\hline \multirow{2}{*}{ Month } & \multicolumn{3}{|c|}{ Ambient air temperature, ${ }^{\mathbf{0}} \mathbf{C}$} & \multicolumn{3}{c|}{ Deep soil temperature at different } \\
& & & & \multicolumn{2}{c||}{ depths, $\mathbf{~ m}$} \\
\cline { 2 - 7 } & Maximum & Minimum & Mean & $\mathbf{1}$ & $\mathbf{2}$ & $\mathbf{3}$ \\
\hline June & 34.7 & 22.0 & 28.5 & 26.4 & 24.3 & 22.8 \\
\hline July & 35.9 & 23.6 & 29.8 & 28.1 & 25.4 & 23.2 \\
\hline August & 36.9 & 24.3 & 31.0 & 29.2 & 26.1 & 23.5 \\
\hline Mean & $\mathbf{3 5 . 8}$ & $\mathbf{2 3 . 3}$ & $\mathbf{2 9 . 8}$ & $\mathbf{2 7 . 9}$ & $\mathbf{2 5 . 2}$ & $\mathbf{2 3 . 2}$ \\
\hline
\end{tabular}

\subsection{Effectiveness of earth-tube heat exchanger}

The monthly average daily temperature (operation period) of inlet airflow, outlet airflow temperature, peripheral deep soil temperature at 3 $m$ deep, thermal efficiency and energy exchange rate of (ETHE) throughout the summer months June, July and August of 2012 are summarized and listed in Table (3). This Table obviously shows that, the thermal efficiency of earth-tube heat exchanger was continuously variable depending upon the temperature difference between inlet and outlet earth-tube airflow temperatures, and temperature difference between inlet airflow and peripheral deep soil. It also reveals that, the lowest value of thermal efficiency was $70.97 \%$ occurred on June month when the daily average cooling temperature for the earth-tube between airflow inlet and outlet was $6.6^{\circ} \mathrm{C}$ also, the lowest value of cooling energy exchange $(2.63 \mathrm{kWh} /$ day $)$. Whilst, the greatest magnitude of thermal efficiency was achieved $(77.48 \%)$ occurred on August and consequentially, the greatest magnitude of cooling energy exchange (3.42 $\mathrm{kWh} /$ day). From Table (3), the average overall thermal cooling efficiency was $73.85 \%$ and the seasonal average daily energy exchange rate throughout the experimental work was $2.75 \mathrm{kWh} /$ day.

Table (3): Monthly average daily inlet airflow earth-tube temperature $\left(T_{a i}\right)$, outlet airflow $\left(T_{a o}\right)$, soil temperature at $3 \mathrm{~m}$ deep $\left(T_{s}\right)$, overall thermal efficiency

$(\eta)$ and heat exchange rate $\left(Q_{e x c}\right)$ throughout the summer season of 2012

\begin{tabular}{|c|c|c|c|c|c||}
\hline Month & $\boldsymbol{T}_{\boldsymbol{a} \boldsymbol{i}},{ }^{\mathbf{0}} \mathbf{C}$ & $\boldsymbol{T}_{\boldsymbol{a} \boldsymbol{o}},{ }^{\mathbf{0}} \mathbf{C}$ & $\boldsymbol{T}_{\boldsymbol{s}},{ }^{\mathbf{}} \mathbf{C}$ & $\boldsymbol{\eta c}, \boldsymbol{\%}$ & $\begin{array}{c}\boldsymbol{Q}_{\text {exc }}, \\
\mathbf{k W h} / \mathbf{d a y}\end{array}$ \\
\hline June & 32.1 & 25.5 & 22.8 & 70.97 & 2.63 \\
\hline July & 33.1 & 25.9 & 23.2 & 73.12 & 2.88 \\
\hline August & 34.6 & 26.0 & 23.5 & 77.48 & 3.42 \\
\hline Mean & $\mathbf{3 2 . 7}$ & $\mathbf{2 5 . 8}$ & $\mathbf{2 3 . 2}$ & $\mathbf{7 3 . 8 5}$ & $\mathbf{2 . 7 5}$ \\
\hline
\end{tabular}

The seasonal average hourly thermal efficiency of the earth-tube heat exchanger related to the inlet airflow temperature is illustrated in Figure (6).The seasonal average hourly thermal energy exchange which related 
to the inlet airflow temperature is illustrated together in Figure (7). This figure shows that a direct relationship between the energy exchange rate and the inlet air flow temperature.

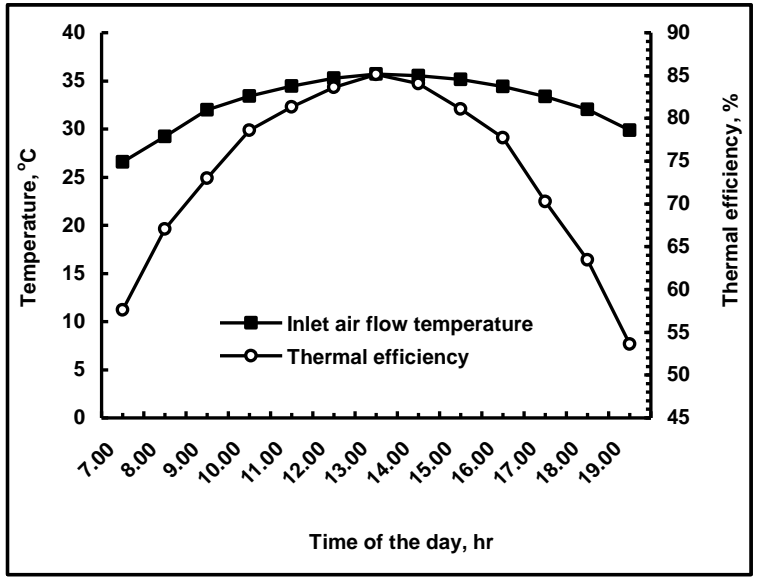

Figure (6): Hourly average thermal efficiency of earthtube heat exchanger related to the inlet airflow temperature for summer season of 2012

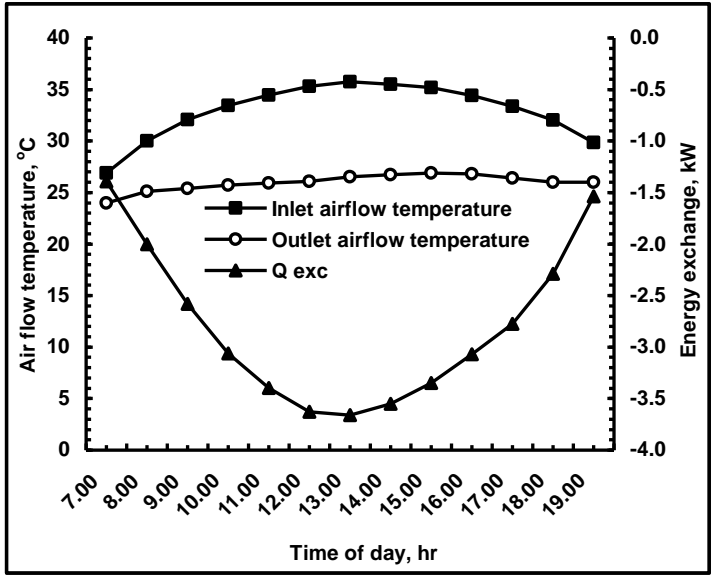

Figure (7): Seasonally average cooling energy exchange rate related to the inlet and outlet airflow temperature during summer season of 2012

\subsection{Effect of earth-tube heat exchanger and evaporative cooling systems on the indoor microclimatic conditions}

For the duration of the experimental work, the seasonal average hourly outdoor and indoor air temperatures for the two greenhouses (G1 and G2) are shown in Figure (8). From the figure, it is seen that the greenhouse (G1) air temperatures ranged between 21.9 and $32.1^{\circ} \mathrm{C}$ with an average of $26.3^{\circ} \mathrm{C}$. This is due to the excess thermal energy loss of the enclosed air to the soil with the help of the EAHE arrangement. Meanwhile, the minimum and maximum temperatures of the air in the greenhouse $(\mathrm{G} 2)$ are observed to be in the range of $21.6-29.4^{\circ} \mathrm{C}$ with an average of $25.7^{\circ} \mathrm{C}$. This figure obviously shows that, the indoor air temperatures for the two greenhouses (G1 and G2) were at and around the optimum daylight air temperature. This due to the earth-tube heat exchanger and evaporative reduced the air temperature inside the two greenhouses as compared with the ambient air temperature also; the indoor air temperature was continuously lower than the outdoor air temperature during daylight time. From Figure (8) the hourly average indoor air temperature for the two greenhouses (G1 and G2) were lowered than the ambient air temperature 
$\left(29.6^{\circ} \mathrm{C}\right)$ by 3.3 and $3.9^{\circ} \mathrm{C}$, respectively. The hourly average vapour pressure deficit (VPD) inside the two greenhouses (G1 and G2) was plotted in Figure (9). It evidently reveals that, the vapour pressure deficit of the air surrounding the cucumber plants increased gradually with time from $0.768 \mathrm{kPa}(\mathrm{G} 1)$ and $0.561 \mathrm{kPa}(\mathrm{G} 2)$ at 5.00 hour until they reached the maximum values (1.905 and $1.60 \mathrm{kPa}$, respectively) at 14.00 hour, as the indoor air temperature increased, and the air relative humidity decreased. The vapour pressure deficit inside the two greenhouses (G1 and G2) showed the same trend during the cooling period. Several studies (Bailey, 1995; Elad et al., 1996; Pringer and Ling, 2004; Argus, 2009) that explored disease pathogen survival at different climate levels revealed two critical values of air vapour pressure deficit. The studies showed that fungal pathogens survive best below vapour pressure deficit of $0.43 \mathrm{kPa}$. Furthermore, disease infection is most damaging below $0.20 \mathrm{kPa}$, which may occur at nighttime with too high air relative humidity $(>80 \%)$ and very low air temperature $\left(<14^{\circ} \mathrm{C}\right)$. The obtained data of air vapour pressure deficit inside the two greenhouses revealed that, the VPD at night was at and around the optimum level (VPD $\geq 0.43$ $\mathrm{kPa}$ ). Heat stress and water stress namely occurred during daylight time when the vapour pressure deficit increased over $2.0 \mathrm{kPa}$ (VPD > 2.0 $\mathrm{kPa}$ ). Also, the obtained data of air vapour pressure deficit inside the two greenhouses revealed that, the average VPD at daylight was at and around the optimum level $(\mathrm{G} 1=1.517 \mathrm{kPa}, \mathrm{G} 2=1.197 \mathrm{kPa}, \mathrm{VPD}<2.0$ $\mathrm{kPa})$.

Monthly average soil profile temperatures are averaged in Table (4). This Table obviously shows that, there are minor differences in soil temperature for the two greenhouses as a result of minor differences in the air temperature. From Table (4) average soil profile temperature around 24 hours with one hour interval was found to be 30.9, 30.2, 29.9 and $29.2^{\circ} \mathrm{C}$ at $0,10,20$ and $30 \mathrm{~cm}$ soil depths, respectively for the greenhouse (G1). Meanwhile, the average soil profile temperature for the same four different depths was found to be $30.9,30.2,29.9$ and $29.2{ }^{\circ} \mathrm{C}$, respectively under the greenhouse (G2). 


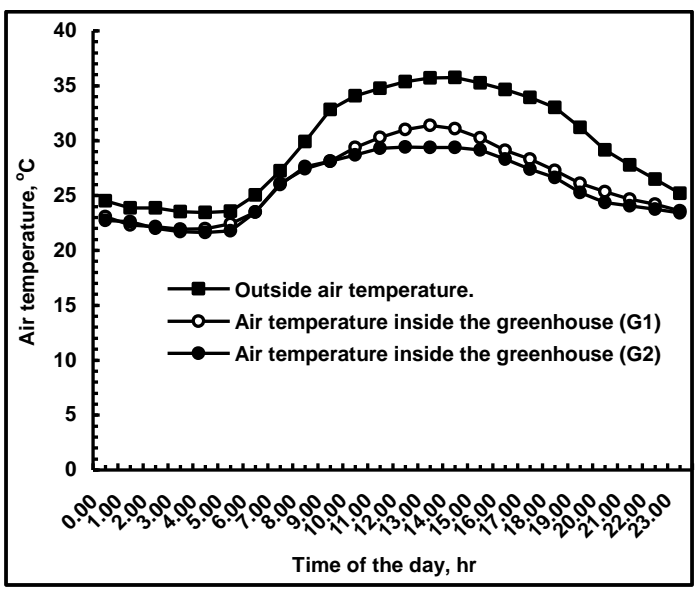

Figure (8): Seasonal average hourly indoor and outdoor air temperatures for the two greenhouses

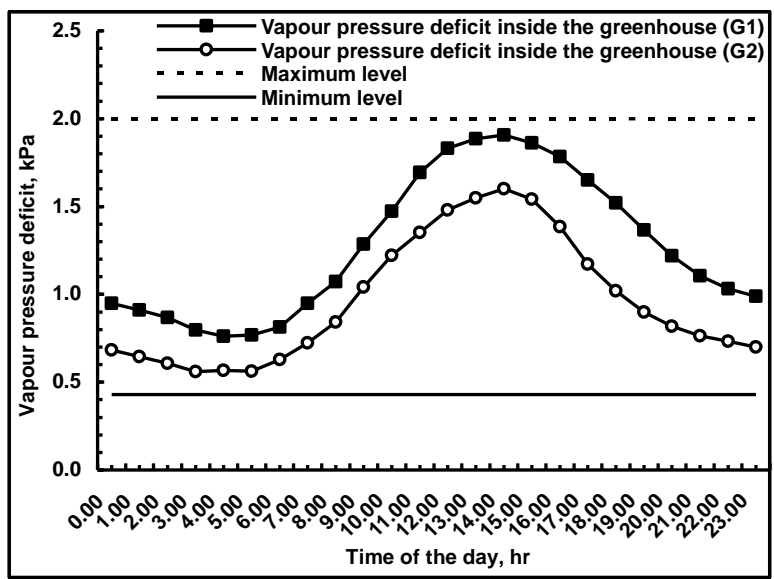

Figure (9): Variations in vapour pressure deficit inside the two greenhouses (G1 and G2) during the cooling period

Table (3): Monthly average soil temperatures for the two greenhouses (G1 and G2) under different soil depths

\begin{tabular}{|c|c|c|c|c|c|c|c|c|}
\hline \multirow{2}{*}{ Month } & \multicolumn{4}{|c|}{$\begin{array}{l}\text { Soil temperature under greenhouse } \\
\text { with earth-tube heat exchanger, }{ }^{\circ} \mathrm{C}\end{array}$} & \multicolumn{4}{|c|}{$\begin{array}{l}\text { Soil temperature under greenhouse } \\
\text { with evaporative cooling, }{ }^{\circ} \mathrm{C}\end{array}$} \\
\hline & $\begin{array}{c}\text { Soil } \\
\text { surface }\end{array}$ & $\begin{array}{l}10 \mathrm{~cm} \\
\text { depth }\end{array}$ & $\begin{array}{l}20 \mathrm{~cm} \\
\text { depth }\end{array}$ & $\begin{array}{l}30 \mathrm{~cm} \\
\text { depth }\end{array}$ & $\begin{array}{c}\text { Soil } \\
\text { surface }\end{array}$ & $\begin{array}{l}10 \mathrm{~cm} \\
\text { depth }\end{array}$ & $\begin{array}{l}20 \mathrm{~cm} \\
\text { depth }\end{array}$ & $\begin{array}{l}30 \mathrm{~cm} \\
\text { depth }\end{array}$ \\
\hline June & 31.2 & 30.4 & 30.2 & 29.1 & 29.2 & 28.8 & 28.4 & 28.2 \\
\hline July & 31.6 & 30.7 & 30.0 & 29.3 & 29.5 & 29.0 & 28.9 & 28.7 \\
\hline August & 29.8 & 29.6 & 29.4 & 29.1 & 28.9 & 28.8 & 28.7 & 28.3 \\
\hline Mean & 30.9 & 30.2 & 29.9 & 29.2 & 29.2 & 28.9 & 28.7 & 28.4 \\
\hline
\end{tabular}

\subsection{Effect of Earth-tube Heat Exchanger and Evaporative Cooling Systems on Microclimatic Conditions of Cucumber Growth, Development and Productivity}

The weekly averages stem length of cucumber plants for the two greenhouses (G1 and G2) were 15.19 and $16.92 \mathrm{~cm} /$ week, respectively. The maximum lengths of the cucumber plants inside the two greenhouses, respectively, were 197.5 and $219.9 \mathrm{~cm}$. Because the microclimatic conditions of the two greenhouses were almost at the same, slight variation in stem length occurred according to the reaction rates of various metabolic processes, and the number of leaves as illustrated in Figure (10). After seven weeks from the transplanting operation of the cucumber plants, the maximum flowering rate of 3.04 
and 3.30 flower/plant, respectively, was achieved inside the two greenhouses (G1 and G2). Due to the reasons discussed previously, the number of fruits being seated on the cucumber plants inside the two greenhouses (G1 and G2) was on an average of 24.85 and 27.20 fruit/plant, respectively. Owing to all the previous reasons, the total fresh yield of cucumber crop for the two greenhouses (G1 and G2), respectively, was 212.1 and $237.4 \mathrm{~kg}$ as revealed in Figure (11). Therefore, the greenhouse (G2) was found to be $25.3 \mathrm{~kg}$ more productive that the greenhouse (G1). The previous obtained data may be explained by the fact that, controlled microclimatic conditions within the greenhouse enhancing the absorption rate of nutrient elements, photosynthetic rate, building up the carbohydrates, growth rate, flowering rate, and reducing the time between the vegetative and harvesting stages.

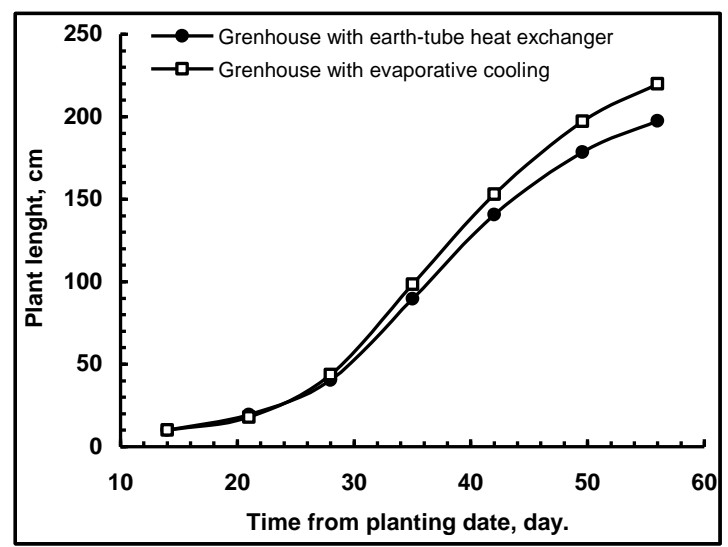

Figure (10): Stem length of cucumber plants for the two greenhouses (G1 and G2) during the summer season of 2012.

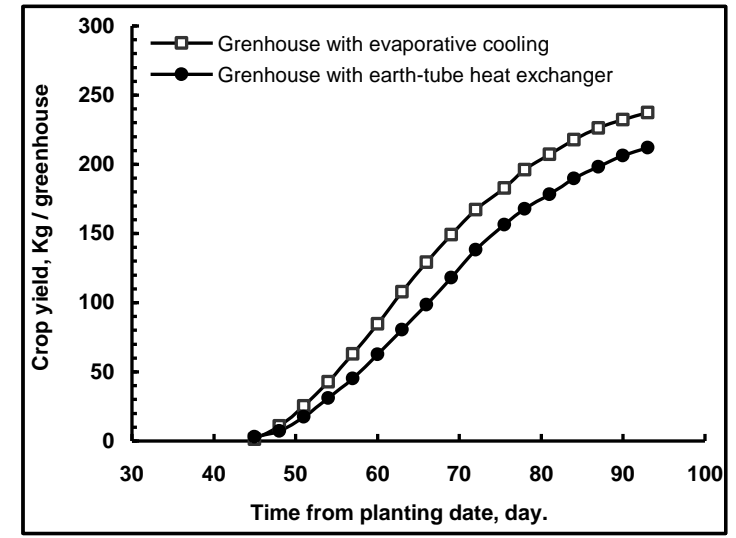

Figure (11): Fresh yield of cucumber crop for the two greenhouses (G1 and G2) during the summer season of 2012.

After the final harvesting operation five samples of cucumber plants were randomly taken from each greenhouse for determining the wet and dry matter weights. The average dry weight for greenhouse (G1) was 68.85 $\mathrm{g} /$ plant, whereas, it was $87.33 \mathrm{~g} /$ plant for the greenhouse (G2). Dry weight was functioned to determine the water consumption during the long growth period. In reality, each 28 grams dry weight of plants consumes 7.5 liters water for the completion of plant growth as stated by Aldrich and Bartok (1990). Accordingly, the annual irrigation water supply to each plant inside the two greenhouses (G1 and G2), respectively, was 18.442 and 23.392 litres/plant. Consequentially, the 
annual irrigation water supply (AIWS) during the summer crop for the two greenhouses (G1 and G2) was 1.770 and $2.246 \mathrm{~m}^{3}$, respectively. The irrigation water-use efficiency (IWUE) for the greenhouses (G1 and G2), respectively, was 119.831 and $105.699 \mathrm{~kg} / \mathrm{m}^{3}$. The annual irrigation water productivity (AIWP) for the two greenhouses (G1 and G2) was 599.2 and $528.5 \mathrm{~L} . \mathrm{E} / \mathrm{m}^{3}$, respectively. From the previous obtained results, the irrigation water-use efficiency for the greenhouse (G1) which equipped with earth-tube heat exchanger system was greater by $13.38 \%$ than that for greenhouse (G2) which provided by evaporative cooling system.

\subsection{Model Evaluation}

The equations were solved using the computer program written in Matlab software (Mathworks, MA, USA). The simulation results which obtained from this model are considered "blind", since they have not been yet compared with that measured within the greenhouse. The comparison between measured and simulated results is very important in order to check out how far the simulated results from the measured ones.

\subsubsection{Air temperature}

To investigate the model's ability to predict and describe greenhouse microclimatic conditions during different times, simulations were compared with that measured and recorded during three consecutive days for each month as follows: 17, 18 and 19 June, 10, 11 and 12 July, 11, 12 and 13 August, 2012. Figure (12) presents the measured and predicted air temperatures inside the greenhouse with earth-tube heat exchanger against simulation period assuming that the state of cover and plant temperatures equal to the simulated values obtained from the model during the simulation periods. It can be seen that the output values obtained by simulation model is very close to the measured values. As shown in Figure (12) the calculation results of the inside air temperatures agree with the measurement data except at the start and top of system operation. The measured air temperature was plotted versus the predicted temperature from simulation model as shown in Figure (13). The closeness of predicted and experimental values has been presented with root mean square of percent. High correlation coefficient between the predicted and measured values of air temperature inside the greenhouse 
was observed. It is seen that, the average values of root mean square of percent deviation during the simulation period of three days for each month was $0.981,0.968$ and 0.974 for the June, July and August, respectively. This shows that the thermal model given by MatLab is in fair agreement with the experimental work for composite climate of Ismailia, Egypt.
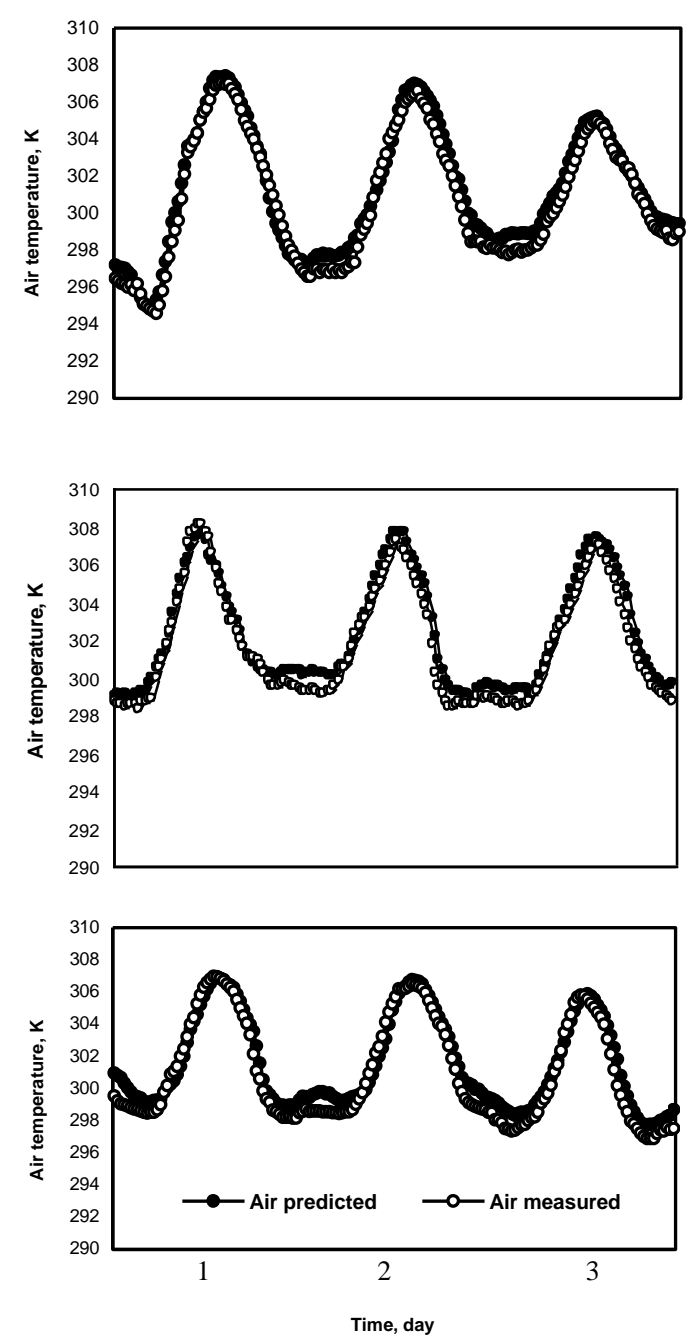

Figure (12): Validation of the measure and predicated indoor air temperatures for the greenhouse (G1) during daylight and at night for three successive days of (a) June, (b) July, and (c) August of 2012
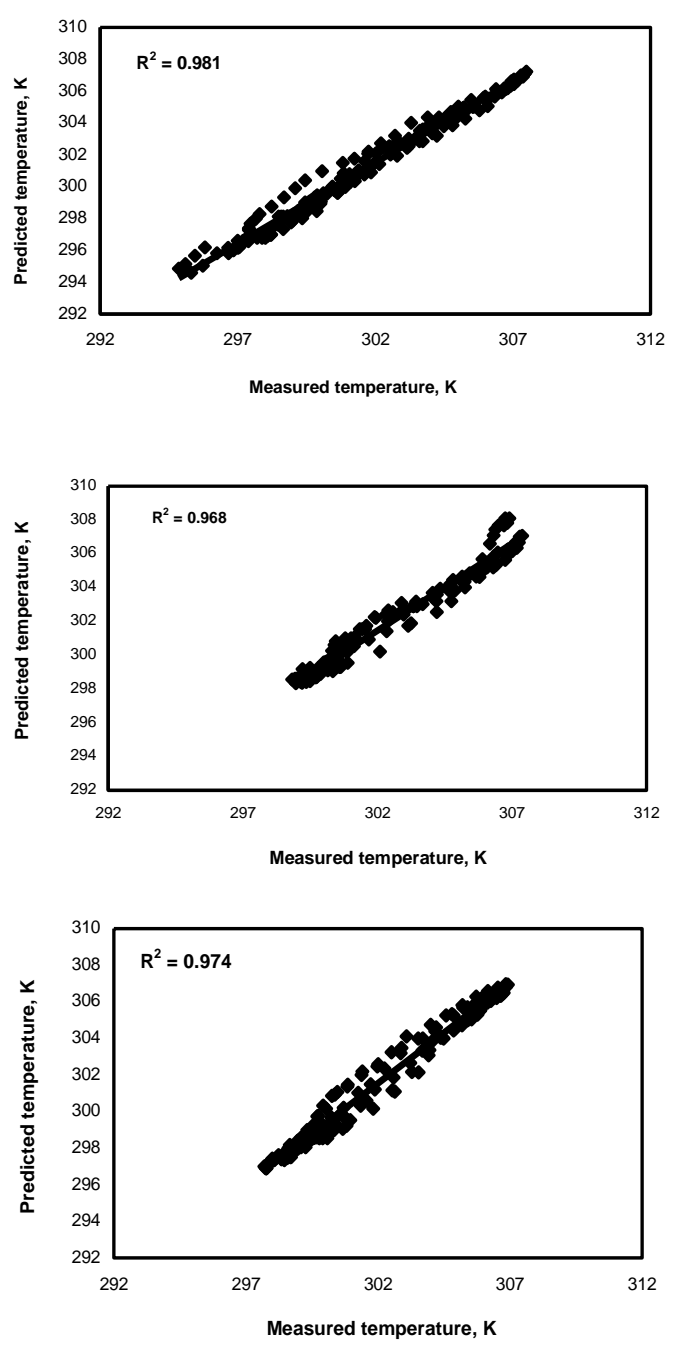

Figure (13): Predicted and measured values for the indoor air temperatures of the greenhouse (G1) during cooling mode; (a) June, (b) July, and (c) August, $\mathbf{R}^{2}$ coefficient of determination. 


\subsubsection{Soil surface temperature}

The simplest mathematical representation of the fluctuating thermal regime in the soil profile is assuming that at all soil depths, the temperature oscillates as a pure harmonic (sinusoidal) function of time around an average value. At each succeeding depth, the peak temperature is dampened and shifted progressively over time. Figure (14) show the measured and predicted soil surface temperature for three successive days. A good agreement can be observed between the simulated soil surface temperature and that measured. The simulation model performed well for predicting soil surface temperature as shown in Figure (15). The coefficient determination of soil surface temperature between predicted and measured values was $0.986,0.961$ and 0.986 for the month of June, July and August, respectively.

\section{CONCLUSION}

- The $3 \mathrm{~m}$ deep soil temperature on average remained constant during the three months period of summer season.

- The monthly average daily overall thermal efficiency for June, July and August months were 70.97, 73.12 and $77.48 \%$ respectively that gave an average overall thermal efficiency of $73.85 \%$.

- The average monthly thermal energy exchange of an earth-tube heat exchanger were found as $2.63,2.88$ and $3.42 \mathrm{~kW}$ for June, July and August months, respectively that gave an average of $2.75 \mathrm{~kW}$.

- Differences between the average soil temperature under the greenhouses containing ETHE and EC are small variation due to the small variation for interior air temperature.

- The output values obtained by simulation model are very close to the measured values. 

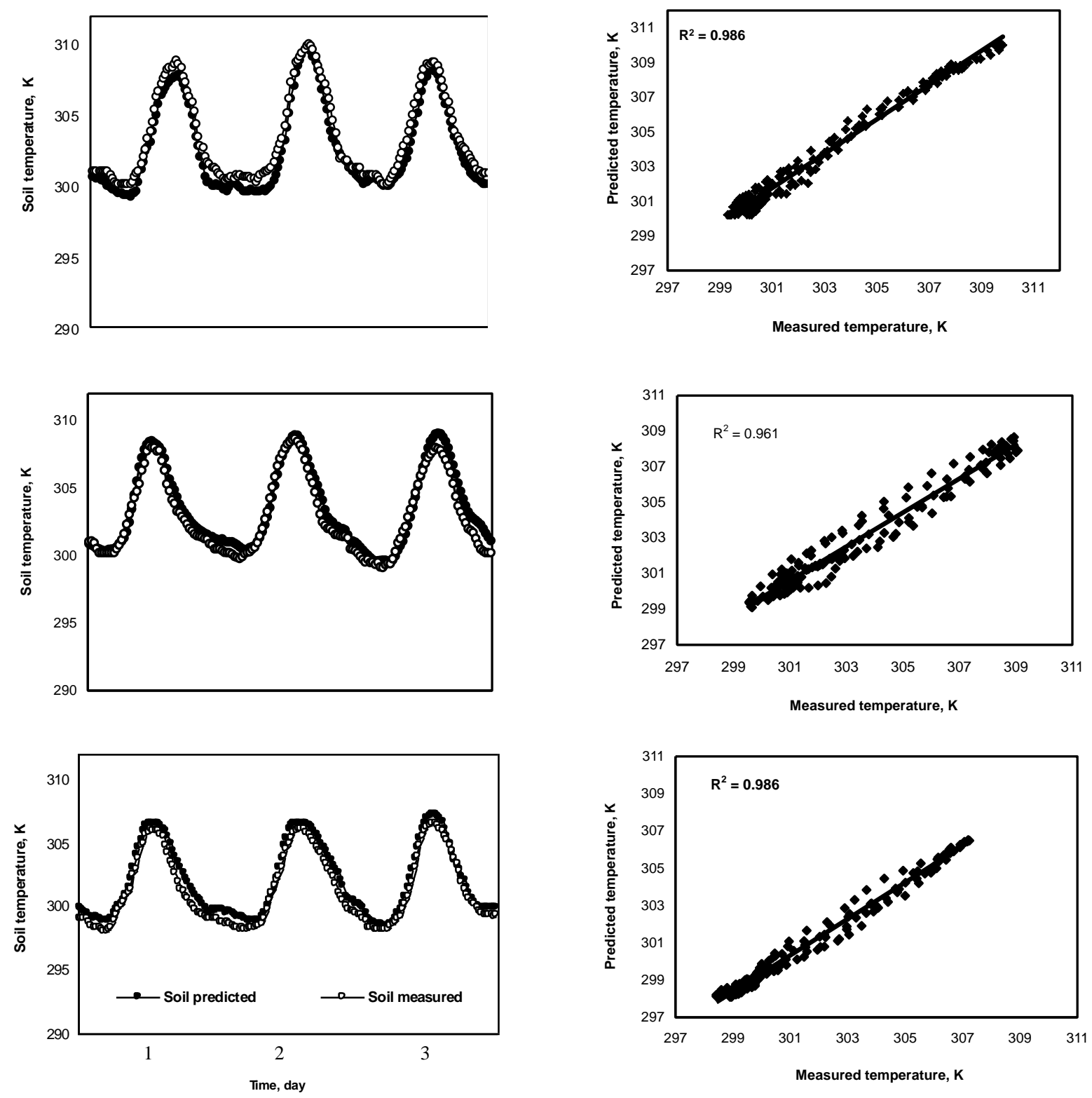

Figure (14): Validation of the measure and predicated Figure (15): Predicted and measured values for the soil temperatures for the greenhouse (G1) during soil temperatures of the greenhouse (G1) during daylight and at night for three successive days of (a) cooling mode; (a) June, (b) July, and (c) August, $\mathbf{R}^{2}$ June, (b) July, and (c) August of 2012 coefficient of determination. 


\section{REFERENCES}

Al-Ajmi, F. ; Loveday, D. L. ; and Hanby, V. I. (2006) "The cooling potential of earth-air heat exchangers for domestic buildings in a desert climate" Building and Environment, 41, 235-244.

Aldrich, R. A. ; and Bartok, J. W. (1990) "Greenhouse engineering" Northeast Regional Agricultural Engineering Service, Comell University, Ithaca, New York, 14853.

Ali, H. M.; Moustafa, S. ; and El-Mansy, H. (1990) "An efficient greenhouse design for hot climates" Energy Conversion Management, 30 (4): 433-437.

ANSI/ASAE STANDARDS, American Society of Agricultural Engineers (2003) "Heating, Ventilating and

Cooling Greenhouses" ANSI/ASAE EP 406.4

Argus Control System LTD (2009) "Understanding and using VPD" www.agruscontrols.com, Canada V4B 3 Y9.

Arnold, K. A. ; Camplell, G. S. ; Nielsen, D. R. ; Jackson, R. D. ; Chair, A. K. ; and Morthand M. M. (1986) "Methods of soil analysis" Part (1) Physical and Mineralogical Methods second edition. American Society of Agronomy, Inc. Ch (15): 383-409.

Ascione, F. ; Bellia, L. ; and Minichiello, F. (2011) "Earth-to-air heat exchangers for Italian climates" Renewable Energy 36, 2177-2188.

Bailey, B. J. (1995) "Greenhouse climate control-new challenges" ActaHorticulturae. 399, 13-23.

Bansal, V. ; Misra, R. ; Agrawal, G. D. ; and Mathur, J. (2010) "Performance analysis of earth-pipe-air heat exchanger for summer cooling" Energy and Buildings, 42, 645-648.

Bisoniya, T. S. ; Kumar, A. ; and Baredar, P. (2013) "Experimental and analytical studies of earth-air heat exchanger (EAHE) systems in India: A review" Renewable and Sustainable Energy Reviews, 19, 238-246. 
Black, C. A. (1965) "Methods of Soil Analysis" Society of Testing and Materials, No A, USA.

Chel, A. ; and Tiwari, G. N. (2010) "Stand-alone photovoltaic (PV) integrated with earth to air heat exchanger (EAHE) for space heating/cooling of adobe house in New Delhi (India)" Energy Conversion and Management, 51, 393-409.

Duffie, J. A. ; and Beckman, W. A. (1991) "Solar Engineering of the Thermal Process Wiley" Interscine New York, USA, 3-44.

Elad, Y. ; Malathrakis, N. E. ; and Dik A. J. (1996) "Biological control of Botrytis-incited diseases and powdery mil-dews in greenhouse crops" Crop Protection. 15(3): 229-238.

El-Sheikh, I. H. (2001) "Soil heating and climate simulation model for greenhouses" Ph.D, Thesis Institute for Techniik in Gratenbau and landwirtschaft, Universitat Hanover, Germany.

Garzoli, K. V. (1985) "A simple greenhouse climate model" Acta Horticulturae, 174, 393-400.

Ghosal, M. K. ; and Tiwari, G. N. (2006) "Modeling and parametric studies for thermal performance of an earth-to-air heat exchanger integrated with a greenhouse" Energy Conversion and Management August, 47 (13-14): 1779-1798.

Ghosal, M. K. ; Tiwari, G. N. ; and Sirivastava, N. S. (2004) "Thermal modeling of a greenhouse with an integrated earth to air heat exchanger, an experimental validation" Energy and Buildings, 36(3): 219-227.

Hassan, A. A. (2001) "Ground Family" Arabic Text Book, Eldar Elarabia Publishing \& Distribution, Cairo, Egypt, PP: 498.

Holman, J. P. (1992) "Heat transfer" McGraw-Hill. McGraw-Hill international book company, London, Hamburg, Paris, Sydney, and Tokyo. 
Ibrahim, M. A. (1999) "Predicting microclimatic conditions in greenhouses" Misr Journal of Agricultural Engineering, 16 (1): $67-$ 82.

Incropera, F. P. ; and Dewitt, D. P. (1996) "Fundamental of Heat and Mass Transfer" John wiley \&Sons: 886.

Jain, D. ; and Tiwari, G. N. (2002) "Modeling and optimal design of evaporative cooling system in controlled environment greenhouse" Energy Conversion and Management, 43, 2235-2250.

Kassem, A. M. (1999) "Possibilities of using soil heat as a renewable source for conditioned greenhouses" Ph. D Science, Department of Agricultural Mechanization, Faculty of Agriculture, El- Mansoura University, Egypt.

Kittas, C. ; Bartzanas, T. ; and Jaffarin, A. (2001) "Greenhouse evaporative cooling: measurement and data analysis" Transactions of the ASAE, 44 (3): 683-689.

Kittas, C. ; Karamanis, M. ; and Katsoulas, N. (2005) "Air temperature regime in a forced ventilated greenhouse with rose crop" Energy and Buildings, 37 (8): 807-812.

Klute, A. (1986): Methods of soil analysis. Physical and Minarological Methods, $2^{\text {nd }}$ Edition, Madison Wisconsin, USA.

Kumar, K. S. ; Tiwari, K. N. ; and Madan, K. (2009) "Design and technology for greenhouse cooling in tropical and subtropical regions: A review" Energy and Buildings, 41, 1269-1275.

Kumar, R. ; Ramesh, S. ; and Kaushik, S. C. (2003) "Performance evaluation and energy conservation potential of earth-air-tunnel system coupled with non- air-conditioned building" Building and Environment, 38, 807-13.

Lewis, M. J. (1990) "Physical properties of foods and food processing system" Ellis Horwood limited. 
Li, H. ; Yu. Y. ; Niu, F. ; Shafik, M. ; and Chen, B. (2014) "Performance of a coupled cooling system with earth-to-air heat exchanger and solar chimney" Renewable Energy, 62, 468-477.

Mc Adams (1954) "Heat Transmission" $3^{\text {rd }}$ edition, Mc Graw - Hill Book Company, New York, USA.

Mujahid, A. M. ; and Alamoud, A. R. (1988) "An easily designed and constructed photovoltaic pyrheliometer" Solar \&Wind Technology, 5 (2): 127-130.

Nelson, V. P. (1990) "Greenhouse operation and management" Third Edition, A Reston Book, Prentice-Hall, Inc, Englewood cliffs, New Jersey, USA, 598pp.

Norton, B. (1992) "Solar Energy thermal technology" Springer- Veriag, London, 279.

Pieters, J. G. ; Deltour, J. M. ; and Debruyckere, M. J. (1994) "Condensation and static heat transfer through greenhouse cover during night" Trans, ASAE, 37(6) 1965-1972.

Pringer, J. J. ; and Ling, P. P. (2004) "Greenhouse condensation control; Understanding and using vapour pressure deficit" Extension Fact-sheet, Ohio Sate University Extension, USA.

Pringer, J. J. ; and Ling, P. P. (2004) "Greenhouse condensation control; Understanding and using vapour pressure deficit" Extension Fact-sheet, Ohio Sate University Extension, USA.

Sethi, V. P. ; and Sharma, S. K. (2007) "Survey of cooling technologies for worldwide agricultural greenhouse applications" Solar Energy, $81,1447-1459$.

Shukla, A. ; Tiwari, G. N. ; and Sodha, M. S. (2008) "Experimental study of effect of an inner thermal curtain in evaporative cooling system of cascade greenhouse" Solar Energy, 82 (1): 61-72.

Sonntage, R. ; and Borgnakke, C. (1988) "Fundamental of Thermodynamics ( $S^{\text {th }}$ edit)" Computer Aided thermodynamic 
Tables 2 (CATT2) developed by Intellipro,Ggordon van wylen John wiley \& Sons, Inc.

Taha, A. (2003) "Simulation model of energy fluxes in passive solar greenhouse with concrete North wall" ph.D, Thesis Institute for Techniik in Gratenbau and landwirtschaft, Universitat Hanover, Germany.

Tiwari, G. N. ; Akhtar, M. A. ; Shukla, A. ; and Khan, E. M. (2006) "Annual thermal performance of greenhouse with an earth-air heat exchanger: An experimental validation" Renewable Energy, 31, 2432-2446.

Woodson T. ; Coulibaly, Y. ; and Traore E. S. (2012) "Earth-air heat exchangers for passive air conditioning: case study Burkina Faso" Journal of Construction in Developing Countries, 17 (1): 21-33

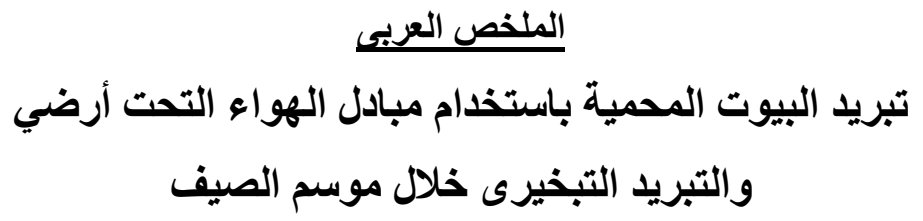

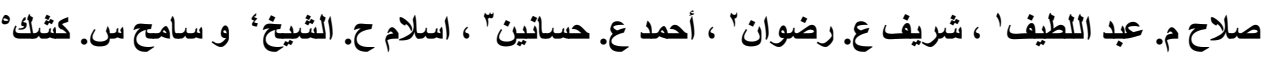
تهدف الدراسة إلى استخدام مبادل الهو اء التحت أرضى لتوفير الظروف المثلى لنمو محصول

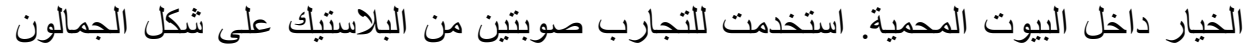

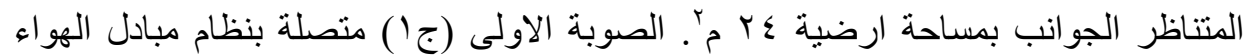

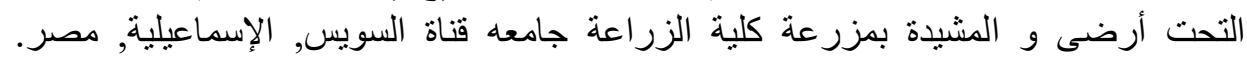

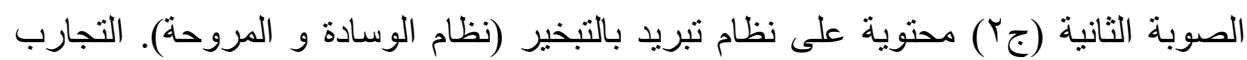

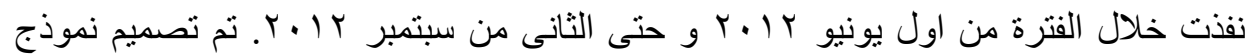

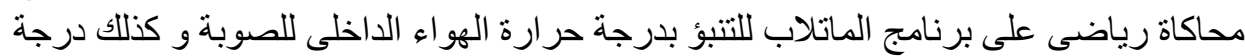

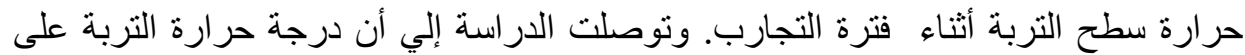

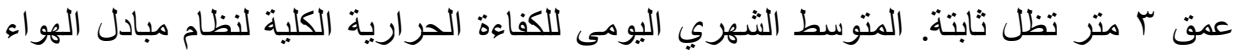

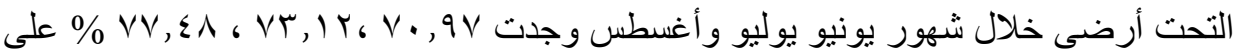

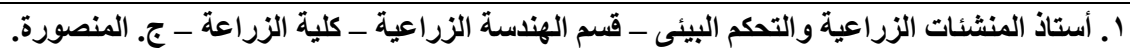

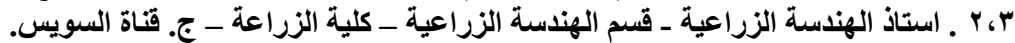

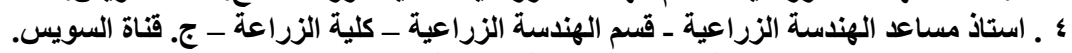

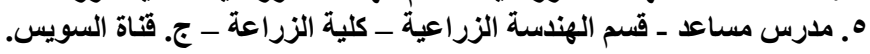


المتوسط الثهرى اليومى لكل ساعة لمعدل التبادل الحراري لنظام مبادل الهواء التحت أنداء أرضى

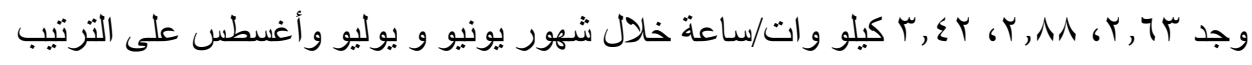

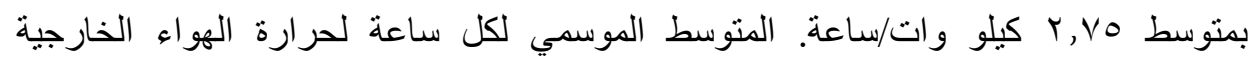

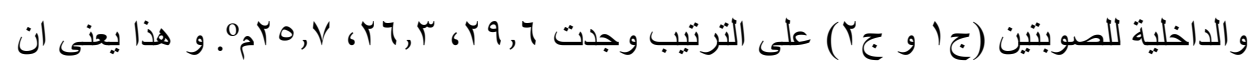

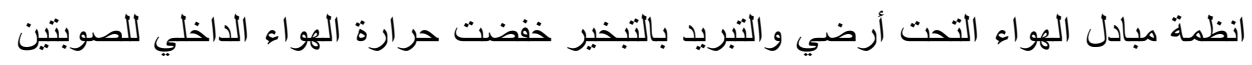

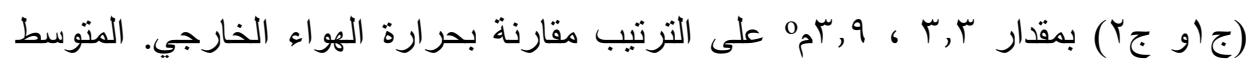

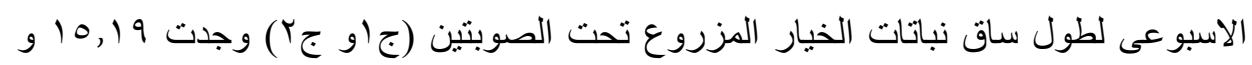

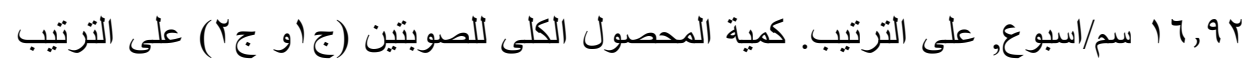

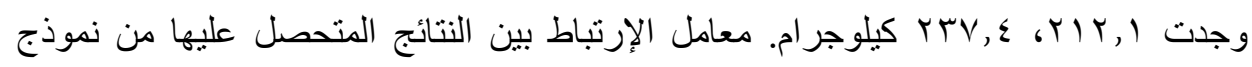

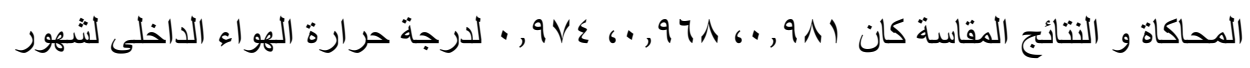

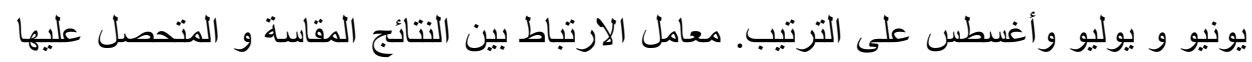

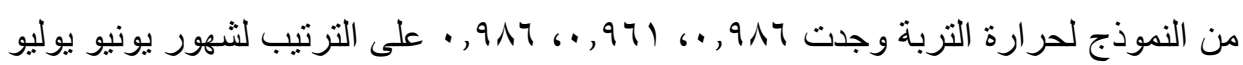
و أغسطس. 